\title{
Ideał życia monastycznego w Pouczeniach wielebnym mniszkom o tym, czego od nich wymaga życie monastyczne św. Teofana Pustelnika
}

\author{
Irena Saszko \\ Хмельницький національний університет \\ Ukraina \\ ORCID: 0000-0003-2077-257X \\ irenasaszko@gmail.com
}

I. Saszko, The Ideal of the Monastic Life In The Instructions to the Reverend Nuns About What Monastic Life Requires Of Them By St. Theophan the Recluse, Elpis, 21 2019: 79-86.

\begin{abstract}
The Instructions to the Reverend Nuns About What Monastic Life Requires Of Them is the collection of 20 sermons of the Orthodox bishop and archimandrite St. Theophan the Recluse (1815-1894). He preached them out to the nuns from different hermitages of the Diocese of Tambov and the Diocese of Vladimir of the Russian Orthodox Church in the years 1859-1864. The main theme of The Instructions is revealing of the aim and the sense of monastic life, especially in its community aspect. The Instructions include many references to the hesychast spirituality. Theophan not only practiced it himself, but introduced into it his spiritual daughters as well. In view of the hesychast advices, the article presents the characteristic of the interior and exterior life of the monks and nuns and understanding of the monastic community as an icon of the Church.

Streszczenie: Pouczenia wielebnym mniszkom o tym, czego od nich wymaga życie monastyczne to zbiór 20 kazań prawosławnego biskupa oraz archimandryty - św. Teofana Pustelnika (1815-1894). Wygłosił je w latach 1859-1864 do mniszek z różnych pustelni Diecezji Tambowskiej oraz Włodzimierskiej Rosyjskiego Kościoła Prawosławnego. Przewodnim tematem Pouczeń jest ukazanie celu i sensu życia monastycznego, zwłaszcza w jego wymiarze wspólnotowym. Pouczenia zawierają wiele odniesień do duchowości hezychastycznej, którą Teofan nie tylko sam praktykował, ale i wprowadzał w jej arkana swoje córki duchowe.W perspektywie zaleceń hezychastycznych w artykule została przedstawiona charakterystyka wewnętrznego i zewnętrznego życia mnichów i mniszek oraz pojmowanie wspólnoty monastycznej jako ikony Kościoła.
\end{abstract}

Keywords: St. Theophan the Recluse, monastic life, spiritual doctor, hesychasm, monastic community

Slowa kluczowe: St. Theophan the Recluse, monastic life, spiritual doctor, hesychasm, monastic community

Życie monastyczne jest życiem bardzo dynamicznym i twórczym. Monaster jest miejscem zarówno nieustannego rozwoju duchowego, jak i urzeczywistniania wolności ku miłowaniu. Słowo Boże domaga się od każdego chrześcijanina, a przede wszystkim od osoby Bogu poświęconej, nie tylko wytężonego zmagania duchowego (gr. atlos, cs. podwig) w celu osiągnięcia nagrody nieprzemijającej, lecz przede wszystkim proegzystencji, czyli życia w bezwarunkowym dawaniu siebie. Jednak „aby otworzyć się na miłość, należy nieustannie wyrywać się ze stanu nie-miłości" [Delfieux 2012, 14]. Miłość jest relacją osobową. Miłość jest twórcza, gdyż we wzajemnej przejrzystości i otwartości bracia i siostry podążają w kierunku budowania głębokich więzi wspólnotowych (gr. koinonia, łac. communio), coraz bardziej odzwierciedlających immanentne życie Trójcy Świętej [Левицкий 2011, 178-180]. Życie monastyczne to milczący, lecz w pełni rzeczywisty udział w żywej historii Kościoła i świata (Пeльтье 2015, 86].

Głosicielem szczególnej wartości monastycyzmu był święty biskup Teofan Pustelnik (1815-1894). Wybrał taki właśnie model życia i ze wszystkich swych sił zmagał się duchowo, aby w pełni podobać się Bogu. Ponadto przez wiele lat kierował formacją duchową mniszek z Diecezji Tambowskiej oraz Włodzimierskiej'. Uczył je kontrolowania swoich myśli (gr. logismoi, cs. pomysty) i zachowywania uwagi serca (gr. prosoche kardias), aby mogły

Gieorgij Wasiljewicz Goworow, znany jako Teofan Pustelnik lub Zatwornik (Rekluz) był - jak wskazuje przydomek - wielkim ascetą i pustelnikiem (28 lat spędził w monasterze, z czego 22 lata jako anachoreta). Przed tym jednak zdążył zdobyć tytuł doktora teologii w Kijowskiej Akadmii Duchownej. Jako wysokiej rangi intelektualista był wykładowcą, a wkrótce został także rektorem Akademii Duchownej w Petersburgu, uczestniczył w rosyjskiej misji prawosławnej w Jerozolimie, często bywał na Świętej Górze Athos, pracował również jako kapłan przy ambasadzie rosyjskiej w Konstantynopolu. W 1859 r. otrzymał chirotonię na biskupa najpierw tambowskiego i szackiego, a w 1863 r. został przeniesiony do Diecezji Włodzimierskiej. Jako archimandryta troszczył się o wykształcenie rosyjskiego duchowieństwa, a także jego wierność Bożemu Słowu oraz Tradycji Ojców Kościoła. Znał języki obce. Oprócz rosyjskiego, biegle mówił też w języku francuskim, greckim, hebrajskim i arabskim, studiował i przekładał pisma Świętych Ojców, zgromadził dużą bibliotekę, a także pozostawił po sobie ogromną własną spuściznę teologiczną. Nie mogąc pogodzić się z niskim poziomem życia moralnego ówczesnych duchownych, a także kontrolą Rosyjskiego Kościoła Prawosławnego ze strony państwa, w 1866 r. odszedł w stan spoczynku i zameszkał w Pustelni Zaśnięcia Matki Bożej w Wyszy, w Diecezji Tambowskiej. Kanonizowany w 1988 r. przez Rosyjski Kościół Prawosławny [Тертышников 1999, 8-179]. 
skutecznie walczyć z demonami oraz poddawać własne namiętności/pożądliwości (gr. pathi) przemieniającym Boskim energiom. Dzięki konsekwentnemu i wytrwałemu odrzucaniu różnego rodzaju pożądliwych myśli, nieustannej modlitwie, czystości serca i zażyłości ze Słowem Bożym można dostąpić łaski wyciszenia wewnętrznego (gr. hesychia) oraz beznamiętności (gr. apatheia). Najdoskonalszą formą dojrzałości duchowej mnicha jest beznamiętność. W tym stanie duszy, miłość do Boga i do ludzi wypala wszelkiego rodzaju przejawy ludzkiego egoizmu [Behr-Sigel 2008, 78]. Droga ku beznamiętności została ukazana w 20 kazaniach, wygłoszonych przez św. Teofana Pustelnika w latach 1859-1864 do mniszek z różnych pustelni Diecezji Tambowskiej oraz Włodzimierskiej Rosyjskiego Kościoła Prawosławnego i opublikowanych pt. Pouczenia wielebnym mniszkom o tym, czego od nich wymaga życie monastyczne [Затворник 2007]. Jest to jedna $\mathrm{z}$ ostatnich publikacji książkowych św. Teofana Pustelnika, która została przygotowana do druku przez samego autora w 1892 r., na prośbę o. Andrzeja Wieriowkina - przełożonego Monasteru św. Pantelejmona na Świętej Górze Athos. Dzieło to jest świadectwem niezwykłej mądrości doświadczonego starca (gr. geron), wielkiego intelektualisty i pasterza Kościoła, jakim był św. Teofan Pustelnik, zwłaszcza biorąc pod uwagę fakt, iż wygłaszał je w czasach głębokiego kryzysu duchowego i moralnego, który dotknął Rosyjski Kościół Prawosławny w XIX wieku. Św. Teofan wprowadzał siostry w najgłębsze tajniki życia duchowego, pragnąc, aby na drodze swojego powołania stały się one solą ziemi i światłem dla świata (por. Mt 5,13-14). W swych Pouczeniach dawał konkretne wskazania jak dążyć do osiągnięcia pokoju serca. Przykładem swego życia ukazywał też, jak trwać w ustawicznej modlitwie, skutecznie demaskować zwodnicze strategie duchów sprzeciwu oraz coraz bardziej stawać się osobą wewnętrznie zintegrowaną i zawsze czuwającą. ${ }^{2}$

\section{Cel życia monastycznego}

Prawdziwy mnich (gr. monachos), będąc „od wszystkich oddzielony, jest zarazem ze wszystkimi złączony" [Ewagriusz z Pontu. Pisma ascetyczne. 2007, 300]. Nie żyje już dla siebie, lecz dla Tego, który za niego umarł i zmartwychwstał (por. 2 Kor 5,15). W Chrystusie zaś żyje dla każdego człowieka, potrzebującego pomocy i pocieszenia duchowego, urzeczywistniając przez to największe przykazanie miłości Boga i bliźniego. Zatem osoba Bogu poświęcona, niczym oblubienica z Pieśni nad Pieśniami, ma nieustannie poszukiwać Pana w Eucharystii, w Słowie Bożym, w nauczaniu Kościoła, w nabożeństwach oraz osobistej nieustannej modlitwie, aby móc wprowadzać w Bożą obecność ludzi, których On powierza jej sercu [3aтворник 2007, 57]. Przebywanie w celi nie jest celem samym w sobie. Cela jest uprzywilejowanym miejscem spo-

\footnotetext{
Na Wschodzie mnicha często określa się greckim terminem neptikos, tzn. czuwający, przebudzony [Behr-Sigel 2008, 76].
}

tkania z Osobową Miłością, do której mnich wchodzi, aby zaczerpnąc siły, a wychodzi, aby służyć innym i składać swoje życie ,jako ofiarę żywą, świętą i Bogu przyjemną" (Rz 12,1-2).

W jednym ze swoich kazań św. Teofan Pustelnik przedstawia siostrom z Włodzimierskiego monasteru najważniejsze cele życia monastycznego. Czyni to na podstawie ewangelicznej opowieści o uzdrowieniu chromego nad sadzawką Betesdą (J 5,1-9). Konfrontuje mniszki z zasadniczymi pytaniami egzystencjalnymi: „Kim jesteście? Czy jesteście Sadzawką Owczą dla odwiedzających was chorych na różne duchowe dolegliwości? Czy być może, pozostając $\mathrm{w}$ swoich celach, niczym w pięciu krużgankach, same utożsamiacie się z ludźmi chorymi, którzy szukają uzdrowienia?”. I dodaje: „Czy zatem jesteście uzdrawiającą kąpielą, czy miejscem przebywania chorych?” [Затворник 2007, 74].

Radykalizm powyższych pytań implikuje odpowiedź nie mniej radykalną, a nawet paradoksalną. ,Według mnie, powinnyście być zarówno jednym, jak i drugim. Mniemajcie o sobie jako o chorych, a zarazem dla innych bądźcie uzdrowicielkami chorób duchowych" - nauczał biskup Tambowski. Argumentował to bardzo ważną zasadą duchową. Mianowicie, iż „w życiu zewnętrznym jest tak, iż ubogi nie potrafi podzielić się dostatkiem, a słaby nie może stać się wsparciem dla innych". Zupełnie inaczej jest natomiast w życiu duchowym. Im bardziej ktoś się uniża i czuje się ubogim, słabym, pokornym i maluczkim, tym większe dzieła potrafi dokonywać w Imię Boże. Trzeba bowiem pamiętać, że „moc w słabości się doskonali” (2 Kor $12,9)$ [Затворник 2007, 75]. Nie bez powodu biskup Teofan definiował mnicha jako osobę ukrzyżowaną, którą ze wszystkich stron ranią włócznie i strzały różnego rodzaju pożądliwości/namiętności (gr. pathi) lub pokus demonicznych. Postrzegał on mnicha prawdziwym męczennikiem, w którego sercu rozgrywa się okrutna duchowa bitwa. Zaś jego śluby monastyczne traktował jako obietnicę ,,porzucenia dawnego człowieka, który ulega zepsuciu na skutek zwodniczych żądz, a odnawiając się duchem w swoim myśleniu, przyobleka się w człowieka nowego, stworzonego według Boga, w sprawiedliwości i prawdziwej świętości” (Ef 4,22-24) [Затворник 2007, 16]. „Mnich jest zdumiewającym i pełnym łaski znakiem na ziemi, chociaż na zewnątrz może wyglądać jako bardzo upokorzony. Co więcej, im bardziej jest upokorzony, tym więcej ma w sobie laski” [Затворник 2007, 11].

Zdaniem św. Teofana, osoba, wybierająca drogę życia monastycznego, ma być lekarzem (gr. iatros) dusz ludzkich. Jednak najpierw, poprzez intensywną pracę nad sobą, a także walkę z myślami (gr. logismoi) oraz pożądliwościami/namiętnościami (gr. pathi), ma zdobyć prawdziwą mądrość duchową, która „zstępując w dusze święte, wzbudza przyjaciół Bożych i proroków" (Mdr 7,27). Tacy mnisi to prawdziwe skarby terapii duchowej, gdyż w świetle Bożego Słowa oraz własnego doświadczenia potrafią wnikać w ludzkie serca (gr. kardiognosis) i udzielać mądrych porad duchowych. Mnisi mogą i powinni okazywać niezbędną pomoc duchową wszystkim, 
którzy targani namiętnościami, szukają pomocy duchowej lub odpoczynku w klasztornych murach. Stanowczość św. Teofana Pustelnika w odniesieniu do celu życia monastycznego wydaje się być zadziwiająca. Uważał on, iż właśnie po to zakładano monastery, aby w nich przygotowywać duchowych lekarzy. Według biskupa Teofana bycie doświadczonym duchowym terapeutą jest najważniejszym powołaniem mnicha w Kościele. „Koniecznie musicie stać się duchowymi terapeutami, bowiem tego wymaga od was Kościół i tego od was oczekują wszyscy chrześcijanie" - apelował do mniszek Włodzimierskich [Затворник 2007, 78].

$\mathrm{Z}$ pewnością św. Teofana głęboko poruszyły dramatyczne słowa chromego, leżącego nad sadzawką Owczą: „Panie, nie ma człowieka, aby mnie wprowadził do sadzawki, gdy nastąpi poruszenie wody" (J 5,7). W tych słowach wielu duchowych paralityków zwraca się do ludzi Kościoła $\mathrm{z}$ prośbą o pomoc $\mathrm{w}$ ich wewnętrznych rozterkach i niepokojach. Jezus nauczał Swoich uczniów, iż ,z obfitości serca mówią usta" (Łk 6,45). W tym kontekście nie powinno dziwić ostrzeżenie św. Teofana: „Jeśli ktoś wymawia puste słowa, to znaczy, iż ma pusto zarówno w głowie, jak i w sercu. I nawet puste ma życie [...] A ten, kto wypowiada dobre słowa, jest bogaty we wszelkie dobro" [Затворник 2007, 7]. Zatem, aby mnich mógł przypominać drzewo pochylone od nadmiaru owoców [Saszko 2018, 201], ma on prowadzić intensywne życie duchowe. W świecie panują pożądliwości i trudno jest im się oprzeć, gdyż wydają się być bardzo atrakcyjne. Mając tego świadomość, św. Teofan skłaniał do refleksji: „Jeśli więc przyjdzie jakikolwiek człowiek świecki do monasteru, aby duchowo odpocząć, a spotka w nim te same pożądliwości, to gdzie ma przed nimi się ukryć?”. Świadom wielkiej odpowiedzialności mniszek za ludzi żyjących w świecie, zachęcał je do radykalizmu życia: „Otóż, weźcie sobie mocno do serca to, kim macie się stać i dołóżcie wszelkich starań do tego, abyście się stały takimi, jakimi ludzie pragną was widzieć" [3aтворник 2007, 78].

\section{Wewnętrzne życie mnicha}

Św. Teofan Pustelnik był zdania, iż podstawą wewnętrznego życia mnicha jest wierność ślubom monastycznym. Już sam Chrystus nakazywał dotrzymywać obietnicy danej Bogu: „Słyszeliście również, co powiedziano przodkom: 'Nie będziesz fałszywie przysięgał, lecz dotrzymasz Panu swej przysięgi"” (Mt 5,33) [Затворник 2007, 5]. Święty ostro krytykował panujące wśród mniszek przekonanie, iż duch czasu niejako wymaga większej pobłażliwości w wypełnianiu obietnic składanych Bogu. „Czas nie osłabia reguły monastycznej (cs. ustaw). Można przestać być mnichem. Jednak ten, kto rzeczywiście pragnie nim być, musi przestrzegać nauczania Świętych Ojców. [...] Zatem, jeśli ktoś zmieni zasady monastycyzmu, to całe jego życie nie będzie już ani monastyczne, ani świeckie - stanie się jakąś nową formą, którą nawet trudno będzie określić" [Затворник 2007, 71].
Autor Pouczeń wewnętrzne życie mnicha ukazywał w sposób ikoniczny. Porównywał je do krzyża, świątyni i wędrówki. Krzyż jest Drzewem Życia, z którego płyną obfite strumienie wody żywej. Jeśli mnich na Golgocie własnego serca, postawi swój wewnętrzny krzyż, to jego życie będzie pełne błogosławionch owoców (por. Ps 1,3). Podnóżkiem tego krzyża mają być umartwienia, przez które „rozdziera się ziemia serca, aby w nią mógł wejść krzyż”. Mnich ma być ukrzyżowany dla świata, a świat dla niego (por. Ga 6,14). Nie może już posiadać własnej woli, lecz wszystko ma złożyć w rękach Boga [Затворник 2007, 26-27]. Przyjmując z wdzięcznością osobowy dar Boga, Jego aktywność wobec siebie, mnich dobrowolnie umiera dla wszelkiej autoafirmacji [Малахов 2010, 4041], chęci podejmowania decyzji, a także ,pragnienia posiadania zakamuflowanego egoizmu" [Rupnik 2003, 47]. Ma być na tyle wolny, aby wszystko w nim stało się miłością. Pionowa część krzyża symbolizuje cierpliwość w wypełnianiu obowiązków i zadań, bezpośrednio wypływających z reguły monastycznej (cs. ustaw), a także wierność wobec wyznaczonego rytmu dnia. Natomiast poprzeczna część krzyża oznacza posłuszeństwo. Mnich bowiem już niczego sam nie wymyśla, lecz wszystko czyni w bezwarunkowym posłuszeństwie swoim przełożonym, albo zgodnie z zaleceniami ojca duchowego lub matki duchowej. Nie ufa sobie samemu, lecz staje się całkowicie otwarty, a przez to prosty i pokorny. Umartwienie ożywia wiara, polegająca na osobistej relacji z Bogiem, do której mnich jest powołany w sposób szczególny. Cierpliwość podtrzymuje nadzieja. Nadzieja zaś wybiega naprzeciw bezgranicznej hojności dobrego Boga i wypełnia serce radością z posiadania nieznanego jeszcze daru... Posłuszeństwo natomiast ożywia miłość, która czyni go twórczym i elastycznym. Bez miłości posłuszeństwo przypomina łamanie suchych gałęzi. „Jedynie z miłością wszystko dzieje się lekko, szybko i chętnie" [Затворник 2007, 78, 27-29].

Aby nie ulec pokusie zejścia z krzyża, św. Teofan proponował swoim córkom duchowym przybicie siebie do krzyża przy pomocy czterech gwoździ. Pierwszym gwoździem jest nieustanne powracanie sercem i pamięcią do swojej pierwszej miłości, aby rozpalić w sobie pierwotną gorliwość, według słów, usłyszanych przez św. Jana Apostoła na wyspie Patmos: „Znam twoje czyny: trud i twoją wytrwałość [...]. Ty masz wytrwałość: i zniosłeś cierpienia dla imienia Mego - niezmordowany. Ale mam przeciw tobie to, że odstąpiłeś od twojej pierwotnej miłości” (Ap 2,24) [Затворник 2007, 22-23] Doskonale znając znaczenie tej pierwotnej miłości, św. Teofan przypominał mniszkom z Sezonowskiego monasteru: „Pamiętacie, jak odczułyście w swoim sercu pierwsze pragnienie bycia mniszką? Jak ono było żarliwe? Jak często i słodko ożywiało duszę? Wówczas Pan podał wam swoją dłoń” [Затворник 2007, 13]. Odwoływał się też do tego, jakże ważnego doświadczenia duchowego, w pouczeniach kierowanych do mniszek w Tambowie: „Pan wymalował w waszych sercach Swoje jaśniejące Oblicze". To własnie dzięki temu miały one tyle odwagi, aby całą swoją istotą zjednoczyć się ze 
swoim Oblubieńcem i być Jego oblubienicami. Biskup zachęcał, aby siostry ożywiały w sobie te uczucia, które są, jak ,życiodajne soki w drzewie lub bicie serca”. Bez nich życie monastyczne umiera [Затворник 2007, 15]. Drugim gwoździem, którym mnich lub mniszka mają przybić siebie do krzyża jest wolność od wszelkiego rodzaju patologicznych przywiązań do rzeczy materialnych, albo do czegoś, co jest świeckie lub cielesne, gdyż takie przywiązanie czyni z mnicha bałwochwalcę. Powoduje również zaburzenie stanu duchowej koncentracji (gr. prosoche) i tworzy we wnętrzu mnicha prawdziwy chaos [Затворник 2007, 24]. Jedyne, do czego mają przylgnąc osoby szczególnie poświęcone Bogu całym sercem, to słów Zbawiciela, zawartych w Ewangelii [Затворник 2007, 85]. Trzeci gwóźdź to wierność regule (cs. ustaw), pismom Świętych Ojców, a także poradom duchowych ojców i matek. Ostatnim czwartym gwoździem jest przekonanie umysłu i serca o tym, że mnich umarł dla świata, aby żyć w całkowitym zjednoczeniu z Bogiem w Trójcy Przenajświętszych Osób. Jego serce ma stać się izdebką intymnego przebywania z Nim (por. Mt 6,6) [Затворник 2007, 24].

W oparciu o słowa św. Pawła Apostoła o tym, że każdy człowiek jest świątynią Ducha Świętego (por. 1 Kor 3,16), św. Teofan Pustelnik zachęcał mniszki, aby w swoich sercach, z pierwotną gorliwością, wzniosły prawdziwe duchowe świątynie dla Boga. W taki sposób będą mogły nieustannie kontemplować Jego Oblicze. Miejscem dla tej świątyni ma być serce, oczyszczone przez głęboką skruchę (gr. katanyksis) [Затворник 2007, 44]. Żarliwe łzy żalu za grzechy i niedoskonałości, połączone z modlitwą celnika: „Boże, zmiłuj się nade mną, grzesznym!” (por. Łk 18,13) uczynią mnicha pokornym i otworzą go na przyjęcie daru Bożego miłosierdzia [Затворник 2007, 55]. Fundamentem ma być niezachwiana wiara oraz determinacja żyć zgodnie z wiarą - bez żadnych wątpliwości czy lęku. Kamieniami mają stać się cnoty, m.in. łagodność, opanowanie, cierpliwość, posłuszeństwo, życzliwość i pracowitość, które scementować może tylko miłość, gdyż bez niej wszystko jest niczym (por. 1 Kor 13,2). Umiarkowanie to prawdziwy plan architektoniczny owej świątyni, albowiem wyznacza miarę, wagę oraz ilość zmagań duchowych (gr. podwigi). Będąc nadgorliwym, mnich bowiem może zburzyć całą budowlę. Natomiast tym, co uchroni świątynię „od wilgoci próżności i pochlebstw, od oschłości, zarozumiałości i pychy, a także bycia kapryśnym i niezadowolonym" jest dach pokory. Jak wiadomo, na wierzchołku ma wznosić się krzyż. Na nim więc należy ukrzyżować własne ego. Ogrodzenie wokół świątyni to wierność regule (cs. ustaw) oraz nauczaniu Kościoła. Jeżeli mnich zdecyduje się wejść do tej świątyni przy pomocy uwagi (gr. prosoche), czujności (gr. nepsis), a także trzeźwości duchowej, to zakosztuje prawdziwej kontemplacji, czyli ustawicznej modlitwy serca, która ogrzeje jego wnętrze, niczym wschód słońca, a także wzniesie się do Nieba jako woń kadzidła [Затворник 2007, 44-47]. Zdaniem biskupa Teofana posiadanie daru takiej modlitwy przewyższa nawet posiadanie ,mądrości Salomona, wiary Abrahama, wytrwałości Hioba czy duchowej żarliwości Dawida” [Затворник 2007, 40].
Jeżeli mnich będzie nieustannie kontrował swoje myśli (gr. logismoi) i utrzymywał uwagę w sercu (gr. prosoche kardias), to Pan spocznie na nim w Chmurze Swej Chwały i niczym z Mojżeszem na Synaju, będzie rozmawiał z nim twarzą w twarz [Затворник 2007, 41-42]. Wówczas stanie się on uczestnikiem Energii Światłości Bożej (gr. tou Theou fotos energesthai). Warto zauważyć, że kontroli myśli oraz uwadze serca - istotnym zasadom hezychazmu, św. Teofan w swoich kazaniach poświęcał bardzo dużo miejsca. Charakterystyczne dla jego sposobu myślenia jest następujące wyjaśnienie: „Całe zło pochodzi od myśli. Gdy zaczynają swobodnie się błąkać, wówczas przychodzą podejrzenia, brak ufności, osądzenie, opieszałość, a co za tym idzie chaos i pycha. $Z$ tego powodu myśli należy kontrolować i nie pozwalać im na samowolę. Ten, kto ma uporządkowane myśli, ma też uporządkowane życie. Wysiłek, polegający na utrzymywaniu myślenia we właściwym porządku to uwaga serca" [Затворник 2007, 68]. Zdaniem biskupa Teofana, człowiek nie może uwolnić się od myślenia, ale może dołożyć wszelkich starań, aby jego myśli były dobre i zgodne z wolą Bożą. Za sprawą częstego słuchania Ewangelii może pielęgnować w sobie myśli jasne - pełne Bożego Światła [Затворник 2007, 68].

Symboliczne ujęcie wewnętrznego życia mnicha Teofan upatruje również w wędrówce Izraela przez pustynię. Przypomina, iż Arkę Przymierza z czterech stron otaczały trzy pokolenia, a sama Arka była niesiona przez Lewitów. Podobnie jest $\mathrm{z}$ modlitwą serca. Ze wszystkich stron mają ją rozpalać żarliwe uczucia i nastawienia. Z przodu: wiara, która wprowadza modlącego się w doświadczenie obecności Bożej, nadzieja, iż z ojcowską troską, wysłuchuje On wszystkie nasze modlitwy, a także miłość do świątyni, w której można przebywać „niczym w domu swojego umiłowanego Ојса" [Затворник 2007, 48-49]. Z tyłu, natomiast, należy uzbroić się w zmagania duchowe (cs. podwigi) radosnego nawiedzania świątyni, bez lenistwa i opieszałości. W świątyni zaś należy przebywać cierpliwie i w należytym skupieniu, zachowując czujność serca, a modlitwy wznosić w duchu uwielbienia, poskramiając przy tym swoje zmysły. Od prawej strony serce mnicha ma ogarniać zarówno uwaga, dzięki której staje się możliwe sprowadzenie umysłu do serca, otwartość na natchnienia Ducha Świętego, jak również łagodność i czułość względem wszystkich ludzi, a zwłaszcza wrogów. Owe pobożne nastawienia zwieńcza zakaz umysłowi błąkania się po różnych miejscach, przedmiotach i ludziach, odrzucenie wszelkich kłopotów życiowych i niepotrzebnych zmartwień, które nie pozwalają mnichowi zając się sprawami niebiańskimi, a także wolność od wszelkich pożądliwości/namiętności (gr. pathi, cs. strasti) oraz przywiązań do osób, przedmiotów czy wrażeń. Zdaniem św. Teofana Pustelnika, jedynie takie wewnętrzne nastawienie, potrafi wzbudzić w sercu mnicha ustawiczną modlitwę, do której tak żarliwie nawoływał Apostoł Narodów (por. 1 Tes 5,17) [Затворник 2007, 50]. Nie jest to droga łatwa. Jest ona pełna cierpień, zmagań i porażek. Jednak jedynie „w cieniu takiego wewnętrznego krzyża" może rozwijać się prawdziwa modlitwa serca. Modlitwa bowiem uskrzydla mnicha. 
Czyni go podobnym do wolnego ptaka, który nieustannie wznosi się ku Bogu [Затворник 2007, 50].

Św. Teofan uczył swoje duchowe córki modlitwy prostej, ufnej, pokornej, a nawet dziecięcej. Z Bogiem należy rozmawiać tak jak dziecko z umiłowanym Ojcem. Ponadto ma to być modlitwa uboga, bez słów przemądrzałych i wyniosłych, a jednocześnie krótka, konkretna i nieustanna: w samotności, podczas wspólnego biesiadowania, w celi, w drodze, w świątyni, podczas posiłków i rękodzieła [3aтворник 2007, 40]. Wówczas wewnętrzne życie mnicha zacznie promieniować na zewnątrz, czyniąc go podobnym do samego Chrystusa. Stanie się on piękny pięknością samego Boga. Bóg natomiast wyposaży go we wszystkie Swoje dary: we wszelką moc, mądrość i świętość [Затворник 2007, 56-57].

Co więcej, św. Teofan Pustelnik uważał, iż mnich, który prowadzi głębokie życie duchowe, posiada spojrzenie samego Jezusa, a Jego słowa otrzymują moc Ducha Świętego. Wszak oczy Pana „są jaśniejsze od słońca, bardziej przenikliwe od poranku. Gdy spojrzał z miłością na nierządnicę, uczynił ją poczciwą, gdy zwrócił Swój wzrok na celnika - uczynił go apostołem, spojrzał na Piotra, a strumienie łez głębokiej skruchy (gr. katanyksis) popłynęły $\mathrm{z}$ jego oczu. Dusze, które wpatrują się w Jezusa, są obdarzane darem duchowego wglądu (gr. orasis), przenikającego Niebiosa i wyraźnie dostrzegającego to, co widzialne i niewidzialne" [Затворник 2007, 56]. Biskup Teofan rozmyślał o mocy słów Zbawiciela w następujący sposób: „Jaki jest jego język? Gdy przemówił, rybacy pozostawili swe sieci, a ci, którzy przyszli, aby go pochwycić, zaczęli się Jemu przysłuchiwać. Na Jego słowo uciszały się fale, a opętanych opuszczały demony, chorzy otrzymywali uzdrowienie, a umarli powracali do życia”. Stąd, jeśli życie mnicha jest zakorzenione w Słowie Bożym, to Chrystus daje mu dar słowa, który leczy złamanych na duchu i przewiązuje ich rany [Затворник 2007, 57].

\section{Zewnętrzne życie mnicha}

Zgłębiając pouczenia św. Teofana Pustelnika, można zauważyć, iż niestrudzenie starał się on przekonywać swoje córki duchowe o tym, że prawdziwe życie ma miejsce w sercu, pojmowanym jako duchowe centrum osoby ludzkiej. Wszelkie próby uchodzenia za kogoś lepszego, niż się jest w rzeczywistości, udawana pobożność lub poprawność moralna jest niczym innym, jak tylko zewnętrzną grą, niemającą nic wspólnego z Ewangelią. Jedynie prawda o własnej grzeszności oraz o Bogu, który jest Miłością i Miłosierdziem, pozwala żyć wolnością dzieci Bożych oraz wypełnia prawdziwą radością w Duchu Świętym (por. 2 Kor 3,17). „Po co przyszłyście do monasteru?” - pytał św. Teofan mniszki z Sezenowskiej pustelni żeńskiej [Затворник 2007, 18]. Przestrzegał je bowiem przed tym, aby żadna $\mathrm{z}$ nich nie wstępowała do monasteru bez rozpoznania swej drogi życiowej. Nauczał, iż „dzieło, dla którego porzucają życie w świecie, jest dziełem wielkim i drogocennym. I należy je doprowadzić do końca. Naj- ważniejsze jest to, co wewnętrzne, a to co zewnętrzne jest tylko dodatkiem. Cała potęga życia duchowego polega jedynie na oczyszczeniu serca od pożądliwości” [Затворник 2007, 18]. Ubolewał nad tym, że nie wszystkie mniszki przestrzegają tych zasad, lecz bardzo dużo sił tracą na robienie rzekomej „kariery” w monasterze, na życie wyobrażeniowe, udawane, na pokaz [Затворник 2007, 19]. Ostro potępiał wszelkie przejawy skostnienia i schematyzmu, które prowadzą do przerostu formy nad treścią [Затворник 2007, 33-34]. Przestrzegał też przed laicyzacją życia monastycznego [Затворник 2007, 9].

Warto podkreślić, iż św. Teofan Zatwornik skupiał szczególną uwagę na trzech głównych elementach zewnętrznego życia mnicha. Wyjaśniał siostrom konieczność zachowania wierności regule (cs. ustaw), wskazywał na piękno i wartość nabożeństw liturgicznych, a także wyjaśniał prawdziwy sens szaty monastycznej (cs. ria$s a)$. Według św. Teofana reguła monastyczna porządkuje życie zarówno każdego konkretnego mnicha, jak również całej wspólnoty w taki sposób, aby stworzyć mnichom okoliczności, sprzyjające walce z pożądliwościami. „Nie wykorzenia jednak pożądliwości, gdyż można zewnętrznie zachowywać się idealnie i przestrzegać wszystkich zasad reguły, a serce mieć pełne złych skłonności” [Затворник 2007, 20]. Z tego powodu zewnętrzne życie regułą ma pochodzić z żarliwego pragnienia czystości serca, która polega na „posłuszeństwie bez podstępu, na łagodności, zachowywaniu pokoju i wzajemnej zgody, pomaganiu sobie nawzajem, ustępliwości, braku osądzania, wolności od przywiązań do rzeczy i zwyczajów światowych, pracowitości, zamiłowaniu do samotności, ascezie, a także nieustannej pamięci o śmierci i życiu wiecznym" [Затворник 2007, 58]. Autor Pouczeń porównywał regułę do muru obronnego, za którym można się ukryć „od burzy i zamętu, spowodowanego duchem czasu, marną świecką mądrością oraz pożądliwościami” [Затворник 2007, 45]. Zatem od wierności regule zależy bezpieczeństwo życia duchowego mnicha.

Reguła, $\mathrm{z}$ kolei, nakazuje udział $\mathrm{w}$ przewidzianych przez nią nabożeństwach, które odbywają się w świątyni, należącej zazwyczaj do zespołu klasztornego. Św. Teofan Pustelnik zachęcał mniszki, aby z należytą czcią odnosiły się do kaplicy oraz nie opuszczały żadnych nabożeństw. Niejednokrotnie zewnętrzna postawa mnicha odzwierciedla jego duchowy stan. W podobny sposób piękno i harmonia celebrowanych nabożeństw świadczą o jedności we wspólnocie, zaś chaos i niedbałość w ich odprawianiu i przeżywaniu - o kryzysie życia monastycznego w danym klasztorze [Затворник 2007, 45]. To właśnie mnich w pierwszej kolejności powinien stać się osobą liturgiczną par excellence. Wszak, dzięki mistycznemu działaniu sakramentów oraz terapeutycznemu oddziaływaniu nabożeństw liturgicznych, potrafi nie tylko dogłębnie poznać samego siebie, lecz również służyć swoim bliźnim i okazywać im miłość w sposób twórczy i niepowtarzalny. Ze względu na to, iż w Boskiej Liturgii działa Bóg w Jezusie Chrystusie i w Duchu Świętym, ma ona moc terapeutyczną. Natomiast przemiana duchowa, która dokonuje się 
w osobie ludzkiej pod jej wpływem, jest przemianą ontologiczną, a nie tylko psychologiczną [Гуджеротті 2018, 18-23]. Św. Teofan Pustelnik przestrzegał mnichów przed lenistwem duchowym, obojętnością, a także systematycznym spóźnianiem się na nabożeństwa. Przypominał, iż przywiązanie do celi nie zwalnia mnicha od modlitw wspólnotowych, gdyż Pan udziela Swoich darów tam, gdzie dwóch albo trzech gromadzi się w Jego Imię (por. Mt 18,20). Modlitwa wspólnotowa ma być przeżywana nie w mniejszym skupieniu niż osobista. Z tego względu, wchodząc do świątyni, należy za jej progiem pozostawić wszystkie troski doczesne, kłopoty i zmartwienia oraz stanąć przed Bogiem z sercem skruszonym, ubogim i oddanуm [Затворник 2007, 35-38].

Mówiąc o habicie, św. Teofan Pustelnik wielokrotnie podkreślał, iż nie każdy, kto go zakłada, może nosić zaszczytne miano mnicha (gr. monachos) [Затворник 2007, $58,63]$. Mnichem może być tylko ten, kto jest skoncentrowany na swym duchowym wnętrzu [Затворник 2007, 9]. Można spotkać „osoby świeckie, ubrane w piękne sukienki, które duchowo są prawdziwymi mniszkami. Niestety są też siostry habitowe (cs. mantijnyje), które w sercu swym prowadzą życie świeckie" [Затворник 2007, 20]. „Na świecie jest wielu ascetów, którzy gorliwie szukają Pana. Uważajcie, aby nie pozostawili was w tyle!" - nauczał św. Teofan siostry Tambowskie [Затворник 2007, 58]. „Chwała Panu, jeżeli Jego oczy wśród osób świeckich dostrzegą prawdziwych mnichów. Jednak nie pozwólcie, aby On kiedykolwiek wśród was zobaczył świeckiego, ubranego w szatę monastyczną" [Затворник 2007, 58]. Archimandryta Teofan nazywa habit (cs. riasa) „szatą szczególną”, a nawet „królewską" i „,anielską" [Затворник 2007, 54, 81], bowiem ma ukazywać na zewnątrz głębokie i pełne cnót wewnętrzne życie mnicha. $Z$ tego powodu zachęcał osoby Bogu poświęcone, aby nieustannie troszczyły się o zachowanie jedności swego życia wewnętrznego z życiem zewnętrznym [Затворник 2007, 54]. Jeśli mnich przestanie kontrolować myśli (gr. logismoi), a także przeżywać skruchę serca (gr. katanyksis), wówczas opanuje go duch tego świata i skoncentruje się na ziemskich pragnieniach. Wtedy na nic mu się nie przyda ani noszenie szaty monastycznej, ani nawet przebywanie w celi [Затворник 2007, 60]. Zwać się mnichem może jedynie ten, kto w swym sercu jest nieustannie zjednoczony z Panem. To właśnie posiadanie daru nieustannej modlitwy czyni z osoby ludzkiej prawdziwego mnicha. Co więcej - według archimandryty Teofana - „im więcej mniszek osiągnie taką doskonałość, tym bardziej ich wspólnota stanie się podobna do monasteru" [Затворник 2007, 65].

Św. Teofan bardzo przestrzegał mniszki przed kompromitacją w oczach ludzi świeckich. Powracał do tego tematu niemal w każdym swoim kazaniu. Natomiast 22 października 1863 r., zwracając się do sióstr z Włodzimierskiego klasztoru, poświęcił temu zagadnieniu całe swoje nauczanie. Odnosząc się ze czcią do osób Bogu poświęconych, ludzie świeccy oddają im jedynie „hipotetyczny" szacunek, gdyż nie wiedzą, co mnisi mają w swoich sercach. Św. Teofan skupiał uwagę swoich duchowych córek na Sądzie Ostatecznym. Dobitnie podkreślał krótkotrwałość oraz kruchość ludzkiego życia na ziemi. Mnisi bowiem muszą liczyć się z tym, że po śmierci ich życie wewnętrzne zostanie zweryfikowane z tym, do czego miała ich zobowiązywać szata -monastyczna [Затворник 2007, 45]. Wówczas ich prawdziwymi oskarżycielami staną się ludzie świeccy. Zatem - według św. Teofana Pustelnika mogą oni postawić mnichom m.in. następujące zarzuty:

Myśleliśmy, żeście pokorni, a teraz sądzeni jesteście za pychę i próżność. Myśleliśmy, że obce są dla was nieczyste myśli oraz poruszenia serca, a teraz sądzeni jesteście za pożądliwość oczu i uczuć. Sądziliśmy, że dużo pościcie, a jesteście oskarżeni za obżarstwo. Myśleliśmy, że modlicie się nieustannie, a Bóg was sądzi za brak pamięci o Nim. Myśleliśmy, że dużo pracujecie, a okazuje się, że byliście leniwi i ospali. Myśleliśmy, że jesteście cierpliwi, a jesteście sądzeni za ciągłe narzekanie. Wydawało się nam, że nie miłujecie świata, ani tego, co na świecie, a jesteście oskarżeni razem z tymi, którzy go miłują. Uważaliśmy was za łagodnych, posłusznych, zachowujących pokój, a jesteście potępieni za gniew, brak pokory, brutalność i kłótliwość [Затворник 2007, 45].

„Czy będziemy w stanie znieść takie zarzuty? A staną się one jeszcze bardziej bolące, gdy się okaże, że świeccy pójdą do Pana za swoje cnoty, a my z powodu naszej niedbałości, zostaniemy wrzuceni do piekła" - podsumowuje swoje wywody biskup Teofan [Затворник 2007, 82]. Jego zdaniem mnich powinien być świadomy symbolicznego znaczenia swojego habitu (cs. riasa), aby móc godnie, odpowiedzialnie, a także z wielką pokorą odnosić się do swojego powołania i misji [Затворник 2007, 81]. Monaster bowiem jest miejscem nieustannego „przygotowania”, a mnich - wiecznym uczniem [Прейс 2018, 151], który urzeczywistnia swoją służbę, będąc wolnym w posłuszeństwie oraz posłusznym w wolności [Кіта 2018, 55]. A będzie to możliwe jedynie wówczas, gdy wspólnota monastyczna stanie się prawdziwą wspólnotą (gr. koinonia, łac. communio). Urzeczywistnienie tego celu wymaga otwartości na bliźniego oraz radosnego dzielenia z nim wspólnego losu, zgodnie z poleceniem św. Pawła: „Jedni drugich ciężary noście, a tak wypełnicie prawo Chrystusowe" (Ga 6,2) [Пельтье 2015, 82].

\section{Wspólnota monastyczna jako ikona Kościoła}

Tak, jak dla św. Bazylego Wielkiego, św. Augustyna czy św. Benedykta, tak również dla św. Teofana Pustelnika ideałem życia monastycznego była pierwsza wspólnota Jerozolimska, gdzie ,jeden duch i jedno serce ożywiały wszystkich wierzących. Żaden nie nazywał swoim tego, co posiadał, ale wszystko mieli wspólne" (Dz 4,32) [3aтворник 2007, 66; Прейс 2018, 152]. Francuska biblistka i teolog, Anne-Marie Pelletier, nazywa monaster ,wzorcowym laboratorium koinonii”, gdyz jest on ,przyktadem wspólnoty urzeczywistnionej, doświadczonej $i$ wypróbowanej dlugościq dni, w konkretnej bliskości drugiego 
człowieka, który nie byt wybrany", lecz zostat dany jako dar i wymaga absolutnego przyjęcia [Пельтье 2015, 86]. Ta starochrześcijańska wizja monasteru jest też obecna w nauczaniu św. Teofana Pustelnika. Uważał on, iz monaster ma być miejscem urzeczywistnienia jedności w różnorodności. Złaczeni w milości i powołaniu, bracia i siostry różnia się cnotami oraz wyjątkowościa darów, talentów i charyzmatów, które maja rozwijać dla wspólnego dobra. Tym samym przypominaja ,różnobarwna niwę” lub „,ogród z rozmaitymi drzewami owocowymi” [Затворник 2007, 64]. Św. Teofan troszczyt się o to, aby siostry „,dbaty o siebie nawzajem z miłościa bez obłudy”, a także „zachowywaty honor wspólnoty przed ludźmi z zewnatrz" [Затворник 2007, 64].

Wedlug Świętych Ojców, Kościót nie ma nic wspólnego z ideologia, religia, ,, szkoła duchowości” czy nawet „pobożnościa”, które ostatecznie tylko podsycaja indywidualizm duchowy jego członków. Kościót to Ciało Chrystusa, w które jesteśmy wtaczeni, aby poprzez Ucztę Eucharystyczna dokonata sie przemiana naszego istnienia $w$ żywa relacje mitości [Яннарас 2000, 38, 41]. Kościót jest Wspólnota ludzi przebóstwionych, którzy pozbywszy się swoich pożądliwości, stali się mieszkaniem Trójcy Przenajświętszych Osób (por. Mt 11,27) [Ходр 2006, 79]. Takie pojmowanie Kościoła w szczególny sposób można odnieść do wspólnoty monastycznej, gdyż - zgodnie z nauczaniem św. Bazylego Wielkiego - ,,monaster jest ikona Kościoła” [Варфоломій 2011, 153]. Zapewne to таjac na względzie, św. Teofan z taka stanowczościa potęiat wśród sióstr wszelkie przejawy indywidualizmu. Nawet osobiste zadowolenie z osiaganego postęu duchowego uważał za przejaw pychy i próżności [Затворник 2007, 62]. W wykorzenianiu w sobie grzesznych skłonności do indywidualizmu św. Teofan upatrywat najlepsza strategie prowadzenia walki z demonami. Ze zlymi duchami bowiem nikt nie wygrywa w pojedynkę. Indywidualizm osłabia wspólnote, czyniqc ja podatna na pokusy [Затворник 2007, 68]. Myślenie indywidualistyczne powoduje zawiść i zazdrossć, a przez to prowadzi do niezdrowej rywalizacji. Wartość i potęga wspólnoty monastycznej nie polega na liczbie mniszek, które ja tworza, lecz zależy od osiagniętej przez nia jedności. Aby tę prawdę zilustrować przytaczat historię Gedeona, który wygrat bitwe, majac jedynie trzystu wojowników (por. $S d z$ 7,3) [Затворник 2007, 18].
Św. Teofan Pustelnik nawoływat też do głębokiej skruchy serca, bojaźni Bożej, ascezy, wspólnej modlitwy, pokoju i wspótpracy (gr. synergeia), twierdzac, iż właśnie na tych filarach opiera się życie wspólnotowe [Затворник 2007, 61]. Zapraszat siostry do praktykowania jeszcze większej gościnności serca i domu. Zachęcal, aby z łagodnościq i życzliwościa przyjmowaty tych, którzy je odwiedzaja [Затворник 2007, 81]. W taki sposób, otrzymując i doświadczając w sobie petni miłości Boga, będa wzorem ludzi wdzięcznych, czyli takich, którzy potrafia zwrócić otrzymana miłość w postaci daru z własnego życia. Owa wdzięczność jako ,antropologiczny warunek relacji z Bogiem" implikuje postawe ubóstwa duchowego [Филоненко 2010, 182], które jest niekończacym się ,, mitosnym ogotoceniem" [Яннарас 2003, 73]. Jedynie prawdziwie ubogi $i$ ogolocony mnich, mitujacy innych ludzi, może w petni „,być soba przed Obliczem Boga” [Малахов 2010, 38-39; Saszko 2014, 65]. Oddajac swoje życie Bogu, mnich otrzymuje je ponownie jako życie przyjęte przez Boga, a więc zycie nowe, uszlachetnione i pobtogostawione.

Z powyższej analizy nauczania św. Teofana Pustelnika wynika, że zarówno wewnętrzne, jak i zewnętrzne życie mnicha czy mniszki powinno cechować się dynamiką, ukierunkowaną na bycie w relacji nie tylko z Bogiem, lecz również ze współbraćmi/współsiostrami oraz ludźmi świeckimi. Mnich całą swoją istotą ma wyrażać „komunijność" swojego powołania, zarówno w jego wymiarze wertykalnym, jak i horyzontalnym. Praktykując wzajemne posłuszeństwo - stuchanie siebie nawzajem - mnisi i mniszki toczą nieustanną duchową walkę o to, aby owej tajemnicy relacji, polegającej na wzajemnej miłości, nie sprowadzić do dwóch wypaczonych skrajności: ,ideologii kolektywizmu oraz obojętności indywidualizmu”. Bycie we wspólnocie monastycznej wymaga ustawicznego zaufania i wdzięczności wobec bliźniego [Майнарди 2012, 276-277]. Takie rozumienie życia monastycznego było bardzo bliskie św. Teofanowi Pustelnikowi, który z wielką żarliwością troszczył się o to, aby wspólnoty monastyczne jego córek duchowych wyróżniały się jednomyślnością (gr. homotymadon), współodczuwaniem (gr. syntonia) oraz współdziałaniem (gr. synergeia) we wszystkim, tworząc jedno ciało [Затворник 2007, 64].

\section{Bibliografia}

Behr-Sigel, E. (2008). Miejsce serca. Wprowadzenie w duchowość prawosławną. (A. Kocot, Tłum.). Kraków: Wydawnictwo Uniwersytetu Jagiellońskiego.

Delfieux, P.-M. (2012). Jeruzalem. Księga Życia. Monastyczne Wspólnoty Jerozolimskie. (Miniszka jerozolimska, Tłum.). Ząbki: APOSTOLICUM.

Ewagriusz z Pontu (2007). Pisma ascetyczne. t. 1. (L. Nieścior, Oprac.). Tyniec: Wydawnictwo Benedyktynów.

Rupnik, M.I. (2003). Profetyzm życia konsekrowanego. (E. Do- brzelecka, B. Hylla, Tłum.). Kraków: Wydawnictwo Alleluja.

Saszko, I. (2014). „Rozświetlona przez Śiatłość Trójsłoneczna”. Relacja Theotokos do Osób Trójcy Przenajświętszej w tradycji liturgicznej Kościoła Prawosławnego. Lublin: Prawosławna Diecezja Lubelsko-Chełmska.

Saszko, I. (2018). Maryja - Przewodniczka jaśniejąca Bogiem. Kraśnik: Wydawnictwo MASSA.

Filonenko, A. (2010). Bogoslovie obŝeniâ ievharističeskaâ antro- 
pologiâ. Koinonia 904(1), 175-190 [Филоненко, А. (2010). Богословие общения и евхаристическая антропология. Koinonia 904(1), 175-190].

Gugerotti, C. (2018). Nova lûdina: liturgìne êstvo. (A. Gladûk, Pereklad). Kiiv: Duh ì Litera [Гуджеротті, К. (2018). Нова людина: літургійне єство. (А. Гладюк, Переклад). Київ: Дух і Літера].

Hodr, G. (2006). Prizyv Duha. Cerkov' iobŝestvo. (D. Karateev, Perevod). Kiev: Duh ì Lìtera [Ходр, Г. (2006). Призыв Духа. Церковь и общество. (Д. Каратеев, Перевод). Киев: Дух i Лiтера].

Kìta, M. (2018). Cerkovnij posluh taêvangel's'ka svoboda. W: (K. Sìgov (red.). Svoboda. Avtoritet.. Služìnnâ. Uspens'ki čitannâ (s. 50-63). Kiiv: Duh ì Lìtera [Кіта, M. (2018). Церковний послух та євангельська свобода. W: (К. Сiгов (ред.). Свобода. Авторитет. Служіння. Успенські читання (с. 50-63). Київ: Дух і Літера].

Levickij, S.A. (2011). Tragediâ svobody. Minsk: Izdatel'stvo Belorusskogo Èkzarhata [Левицкий, С.A. (2011). Трагедия свободы. Минск: Издательство Белорусского Экзархата].

Mainardi, A. (2012) Vstreča s bratom. Ot uedineniâ k obŝeniû. W: K. Sigov (red.), Vstreča s bratom.Hristianskoe predanie meždu Vostokom i Zapadom. (s. 269-283). Kiev: Duh ì Litera [Майнарди, А. (2012) Встреча с братом. От уединения к общению. W: К. Сигов (ред.), Встреча с братом. Христианское предание между Востоком и Западом. (с. 269-283). Киев: Дух і Літера].

Malahov, V. (2010). Inoj i neinnoe v obŝenii, Koinonia 904 (1), 15-48 [Малахов, В. (2010). Иной и неинное в общении, Koinonia 904 (1), 15-48].

Pareys van M. (2018). Žittâ v bratnìj spil'notì za Prepodobnimbenediktom. W: K. Sìgov (red.), Svoboda. Avtoritet. Služìnnâ. Uspens'kì čitannâ (144-161). Kiiv: Duh ì Lìtera [Прейс ван, М. (2018). Життя в братній спільноті за преподобним Бенедиктом. W: К. Сігов (ред.), Свобода.
Авторитет. Служіння. Успенські читання (144-161). Київ: Дух і Літера].

Pelletier, A.-M. (2015). Žit' v obŝenii v sobornom duhe. W: K. Sigov (red.), Obŝenie-Communio-Koinonia: stoki, puti osmysleniâi voploŝeniâ. Uspenskie čteniâ (s. 79-88). Kiev: Duh ì Lìtera [Пельтье, А.-М. (2015). Жить в общении в соборном духе. W: К. Сигов (ред.), Общение-Соттипіо-Koinonia: стоки, пути осмысления и воплощения. Успенские чтения (с. 79-88). Киев: Дух і Літера].

Rovčan, V. (2014). Krestinočeskoj žizni. Uspenskij Vyšenskij monastyr' [Ровчан, В. (2014). Крест иноческой жизни. Успенский Вышенский монастырь].

Tertyšnikov, G. (1999) Svâtitel' Feofan Zatvornik i ego učenie ospasenii. Moskva: Pravilo Very [Тертышников, Г. (1999) Святитель Феофан Затворник и его учение о спасении. Москва: Правило Веры].

Varfolomìj, Patrìarh (2011). Vič-na-vič iz Tajnô. Pravoslavne hristiânstvou sučasnomu svitì. (D. Morozova. Pereklad). Kiiv: Duh ì Litera [Варфоломій, Патріарх (2011). Віч-навіч із Тайною. Православне християнство у сучасному cвimi. (Д. Морозова. Переклад). Київ: Дух і Літера].

Yannaras Ch. (2000). Cerkov' - sposob suŝestvovaniâ, sil'nyj pobedit'smert'. (A. Kostromin, Perevod). Pravoslavnaâ obŝina (58), 35-43 [Яннарас, Х. (2000). Церковь - способ существования, сильный победить смерть. (А. Костромин, Перевод). Православная община (58), 35-43].

Yannaras Ch. (2003). Variaciï na temu Pisnìpisen'. (S. Govrun, Pereklad). Kiiv-L'vìv: Duh ì Lìtera. Svičado [Яннарас, X. (2003). Варіації на тему Пісні Пісень. (С. Говрун, Переклад). Київ-Львів: Дух і Літера. Свічадо].

Zatvornyk, Teofan (2007). Nahaduvannia vsechesnym monakhyniam pro te, choho vid nykh vymahaie chernetstvo. (M. Lemyk, Pereklad). Lviv: Svichado [Затворник, Теофан (2007). Нагадування всечесним монахиням про те, чого від них вимагає чернецтвво. (М. Лемик, Переклад). Львів: Свічадо]. 
ISSN 1508-7719

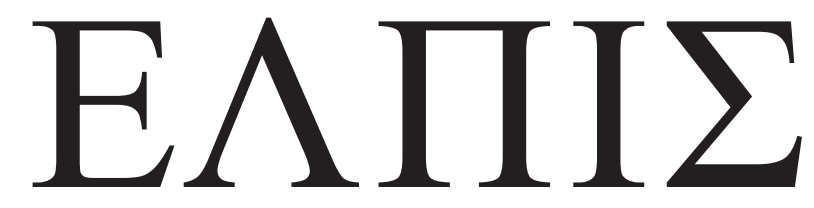

CZASOPISMO TEOLOGICZNE KATEDRY TEOLOGII PRAWOSŁAWNEJ UNIWERSYTETU W BIAŁYMSTOKU

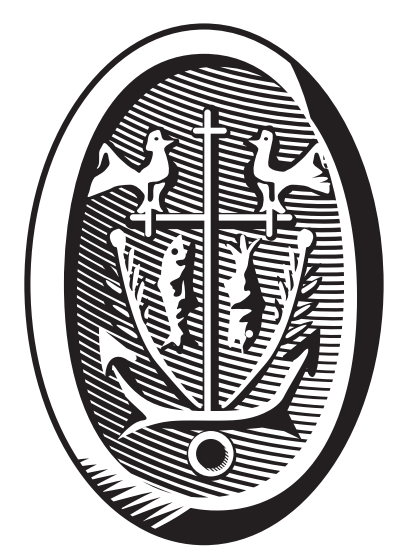

ADRES REDAKCJI

ul. Ludwika Zamenhofa 15, 15-435 Białystok, Polska tel. 85 745-77-80, e-mail: elpis@uwb.edu.pl www.elpis.uwb.edu.pl 